\title{
Evaluation of Some Plant-derived Secondary Metabolites Against Sensitive and Multidrug-resistant Mycobacterium tuberculosis
}

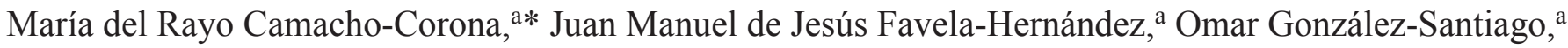 \\ Elvira Garza-González, ${ }^{\mathrm{b}}$ Gloria María Molina-Salinas, ${ }^{\mathrm{c}}$ Salvador Said-Fernández, ${ }^{\mathrm{c}}$ Guillermo Delgado, \\ Julieta Luna-Herrera ${ }^{\mathrm{e}}$
}

a Laboratorio de Química de Productos Naturales, DES Facultad de Ciencias Químicas, Universidad Autónoma de Nuevo León. Guerrero y Progreso, Col. Treviño, Monterrey 64570, Nuevo León, México. maracamcor@hotmail.com

b Departamento de Microbiología, Facultad de Medicina, Universidad Autónoma de Nuevo León. Madero y Eduardo Aguirre Pequeño, Col. Mitras Centro, Monterrey 64460, Nuevo León, México.

c Centro de Investigación Biomédica del Noreste, Instituto Mexicano del Seguro Social, Nuevo León. San Luis Potosí y dos de Abril. Col. Independencia, Monterrey 64720, Nuevo León, México.

d Instituto de Química, Universidad Nacional Autónoma de México. Circuito Exterior, Ciudad Universitaria, Coyoacán 04510, México, D.F. delgado@servidor.unam.mx

e Departamento de Inmunología, Escuela Nacional de Ciencias Biológicas, Instituto Politécnico Nacional. Prolongación de Carpio y Plan de Ayala, México 11340, D.F., México.

Received May 18, 2009; Accepted June 29, 2009

\begin{abstract}
The results on the bioevaluation of thirty five plant-derived secondary metabolites against one sensitive and three multidrugresistant clinical isolates of Mycobacterium tuberculosis are reported. Results toward the sensitive strain showed that five products gave MIC values of $12.5 \mu \mathrm{g} / \mathrm{mL}$ : the alkaloids 6-methoxydihydrochelerytrine (2) and 6-methoxy-dihydrochelirubine (6), the flavanone pinostrobin (17), 1-hydroxy-benzoisochromanquinone (23) and 23-hydroxy-5a-lanosta7,9(11),24-triene-3-one (33). These were followed by the peracetylstrictosidine lactam (12) and the quinone aloe-emodin (24) which displayed MICs of $6.25 \mu \mathrm{g} / \mathrm{mL}$. Finally, liriodenine (8) was the most active (MIC: $3.125 \mu \mathrm{g} / \mathrm{mL}$ ) of all secondary metabolites. Results with the multidrug-resistant clinical isolates showed that 6-methoxy-dihydrochelirubine (6) was the most active (MIC: $12.5 \mu \mathrm{g} / \mathrm{mL}$ ).

Keywords: Mycobacterium tuberculosis, antituberculosis activity, bioactive secondary metabolites, alkaloids, flavonoids, quinones, triterpenes, diterpenes.
\end{abstract}

\section{Introduction}

Tuberculosis remains one of the major deadliest infectious diseases for humans. Approximately 9.2 million people develop the active disease each year, while 1.7 million cases of active disease result in death in the same period. The situation is worsening primarily because the association between tuberculosis and epidemic HIV/AIDS as well as the growing prevalence of multidrug-resistant (MDR) Mycobacterium tuberculosis strains [1]. These acute problems have led to search for structurally effective new drugs against this bacterium.

Part of our area of interest involves the search for structurally novel anti-tuberculosis natural products from higher plants. Plants have been used worldwide in traditional medicines for the treatment of various diseases and it is estimated that even today approximately $65-75 \%$ of the world's population rely only on medicinal plants as their primary source of medicines [2]. The phytochemical study of some of these plants has yielded a number of active natural products $[3,4]$,
Resumen. Se informan los resultados sobre la bioevaluación de treinta y cinco metabolitos secundarios de plantas frente a una cepa sensible y a tres cepas resistentes a múltiples drogas de Mycobacterium tuberculosis. Los resultados frente a la cepa sensible mostraron que cinco metabolitos secundarios poseen valores de CMI de $12.5 \mu \mathrm{g} / \mathrm{mL}$ : los alcaloides 6-metoxidihidroqueleritrina (2) y 6-metoxi-dihidroquelirubina (6), la flavanona pinostrobina (17), 1-hidroxi-benzoisocromanquinona (23) y el triterpeno 23-hidroxi-5a-lanosta-7,9(11),24trien-3-ona (33). La lactama de peracetilestrictosidina (12) y la quinona aloe-emodina (24) mostraron CMIs de $6.25 \mu \mathrm{g} / \mathrm{mL}$. Finalmente, liriodenina (8) fue la substancia mas activa (CMI: $3.125 \mu \mathrm{g} / \mathrm{mL}$ ) de todos los metabolitos secundarios. Los resultados con los aislados clínicos resistentes a multidrogas mostraron que 6-metoxi-dihidroquelirubina (6) fue el compuesto mas activo (CMI: $12.5 \mu \mathrm{g} / \mathrm{mL}$ ).

Palabras clave: Mycobacterium tuberculosis, actividad antituberculosis, metabolitos secundarios bioactivos, alcaloides, flavonoides, quinonas, triterpenos, diterpenos.

thus the screening of natural products from higher plants constitutes one avenue in the search for new lead antitubercular agents. In this study we screened thirty five phytochemicals against one drug sensitive and three multidrug resistant clinical isolates of $M$. tuberculosis using the Alamar Blue assay. The tested secondary metabolites included alkaloids (1-13, scheme 1), flavonoids (14-22, scheme 2), quinones (23, 24, scheme 3), triterpenes (25-33, scheme 4) and diterpenes (34-35, scheme $4)$. The isolation and characterization of the different phytochemicals were described previously [5-14].

\section{Results and Discussion}

Plant derived secondary metabolites 1-35 were evaluated against M. tuberculosis $\mathrm{H} 37 \mathrm{Rv}$ and three MDR isolates (345, M-12 and M-20) and the compounds which displayed activity are listed in Table 1 . Compounds 4, 7, 11, 16, 18-22, 27, 30 and 31 were considered inactive $(\mathrm{MIC}>50 \mu \mathrm{g} / \mathrm{mL}$ for 

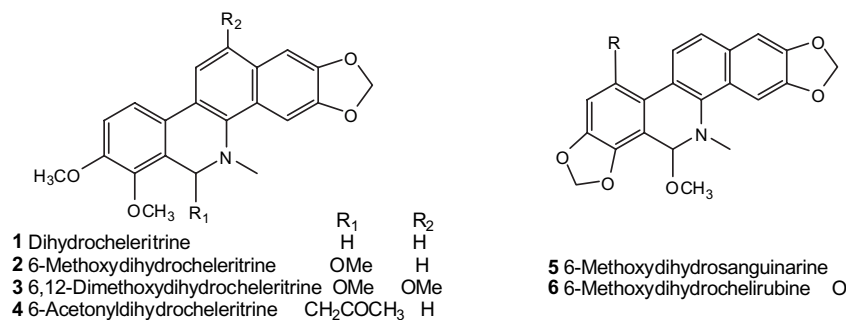

5 6-Methoxydihydrosanguinarine $\stackrel{\mathrm{H}}{\mathrm{H}}$ 6 6-Methoxydihydrochelirubine<smiles>COc1ccc(-c2ccc3cc4c(cc3c2N(C)C)OCO4)c(O)c1OC</smiles>

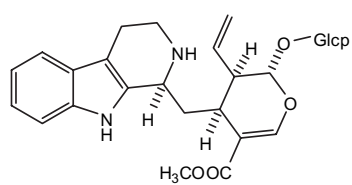

10 Strictosidine<smiles>COc1ccc(CC2c3c(cc(OC)c(OC)c3Oc3cc4c(cc3OC)CCN(C)C4Cc3ccc(Oc4ccccc4OC)cc3)CCN2C)cc1</smiles>
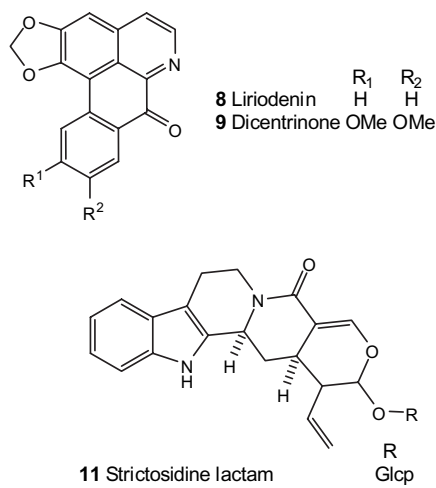
12 Peracetylstrictosidine lactam $\operatorname{Glcp}(\mathrm{Ac})_{4}$

13 Phaeanthine

Scheme 1. Structures of tested alkaloids.<smiles>[R]c1c(O)c(CC=C(C)C)c2c(c1O)C(=O)C[C@H](c1ccccc1)O2</smiles>

14 5,7-Dihydroxy-8-prenyl-flavanone 15 5,7-Dihydroxy-6-methyl-8-prenyl-flavanone $\mathrm{CH}_{3}$<smiles>[R6]Oc1ccc(-c2cc(=O)c3c(O)cc(O)c(-c4cc(-c5cc(=O)c6c(O)cc(OC(=O)O)cc6o5)ccc4O)c3o2)cc1</smiles>

20 Podocarpusflavone A $\begin{array}{ccc}\mathrm{R}_{1} & \mathrm{R}_{2} \\ \mathrm{H} & \mathrm{CH}_{3}\end{array}$ 20 Podocarpusflavone $\mathrm{A} \quad \mathrm{H} \quad \mathrm{CH}_{3}$

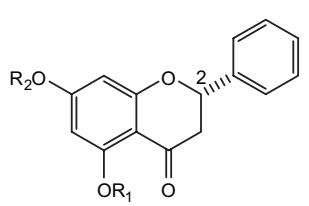

16 Pinocembrin $\quad \mathrm{H} r$

17 Pinostrobin $\mathrm{H}$ CH

$\begin{array}{lll}18 \text { Aceylpinocembrin } & \text { Ac } & \text { Ac } \\ 19 \text { Chrysin } & \text { H } & \text { 2 2,-dehydro }\end{array}$
Scheme 2. Structures of tested flavonoids.

H37Rv and $>200 \mu \mathrm{g} / \mathrm{mL}$ for 345, M-12 and M-20). Results show that seven secondary metabolites exhibited MIC values of $50 \mu \mathrm{g} / \mathrm{mL}$, six had MIC values at $25 \mu \mathrm{g} / \mathrm{mL}$, three presented values of $12.5 \mu \mathrm{g} / \mathrm{mL}$ and two of $6.25 \mu \mathrm{g} / \mathrm{mL}$ and only one had an MIC value of $3.125 \mu \mathrm{g} / \mathrm{mL}$ towards the sensitive strain<smiles>O=C1C2=C(C(=O)c3ccccc31)[C@@H](O)OCC2</smiles>

23 1-Hydroxy-benzoisochromanquinone<smiles>O=C1c2cccc(O)c2C(=O)c2c(O)cc(CO)cc21</smiles>

24 Aloe-emodin
Scheme 3. Structures of tested quinones.

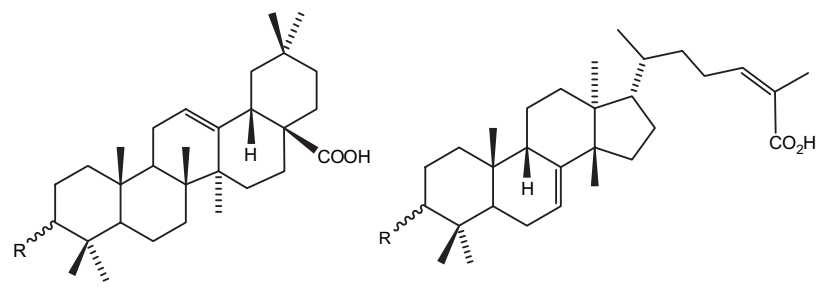

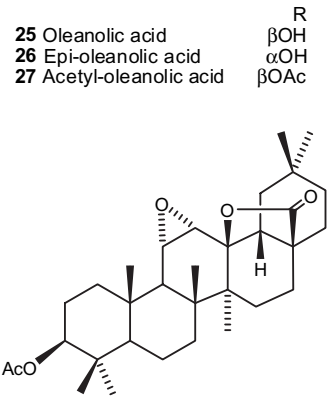

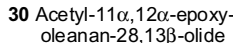<smiles>[Z][C@H]1CC[C@]2(C)C3=CC[C@]4(C)[C@@H]([C@H](C)C[C@@H](O)C=C(C)C)CC[C@]4(C)C3=CC[C@H]2C1(C)C</smiles>

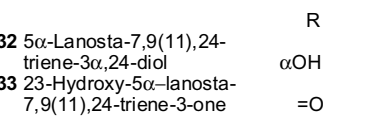

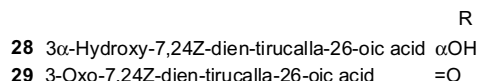

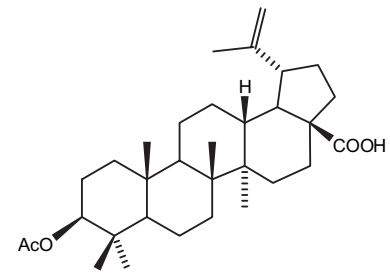

31 Betulinic acid<smiles>[R2][C@H]1C[C@](C)(CO)[C@H]2CCC3=C[C@@](C)(C=C)CC[C@H]3[C@@]2(C)C1</smiles>

scheme 4. Structures of tested triterpenes and diterpenes.

H37Rv. Among those metabolites with moderate activity (MIC: $12.5 \mu \mathrm{g} / \mathrm{mL}$ ) were the flavonoid pinostrobin (17) from Teloxys graveolens, 1-hydroxy-benzoisochromanquinone from Psychotria camponutans (23) and the triterpene 23-hydroxy5-lanosta-7,9(11),24-triene-3-one (33) isolated from Guarea rhopalocarpa. Those with MIC values of $6.25 \mu \mathrm{g} / \mathrm{mL}$ were the alkaloid peracetylstrictosidine lactam (12) from Cephaelis dichroa and the quinone aloe-emodin (24) from Stephania dinklagei. Liriodenine (8) isolated from $S$. dinklagei showed the best activity (MIC: value of $3.125 \mu \mathrm{g} / \mathrm{mL}$ ).

However, the only secondary metabolites that showed good activity against the three MDR $M$. tuberculosis clinical isolates were the alkaloids 6-methoxydihydrocheleritrine (4, MIC 25-50 $\mu \mathrm{g} / \mathrm{ml})$, 6-methoxydihydrosanguinarine (5, MIC 12.5-50 $\mu \mathrm{g} / \mathrm{ml})$ and 6-methoxy-dihydrochelirubine (6, MIC: 
Table 1. Antimycobacterial activity de some secondary metabolites against M. tuberculosis H37Rv and MDR clinical isolates of M. tuberculosis. Compounds 4, 7, 11, 16, 18-22, 27, 30 and 31 were considered inactive (MIC $>50 \mu \mathrm{g} / \mathrm{mL}$ for H37Rv and $>200 \mu \mathrm{g} / \mathrm{mL}$ for 345 , M-12 and M-20).

\begin{tabular}{|c|c|c|c|c|c|c|}
\hline \multirow[t]{2}{*}{$\begin{array}{l}\text { Plant species } \\
\text { (Family) }\end{array}$} & \multirow[t]{2}{*}{$\begin{array}{l}\text { Secondary metabolite } \\
\text { (Type })^{\mathrm{a}}\end{array}$} & \multirow[t]{2}{*}{ Reference } & \multicolumn{4}{|c|}{$\begin{array}{l}\text { M. tuberculosis } \\
\text { MIC }(\mu \mathrm{g} / \mathrm{mL})\end{array}$} \\
\hline & & & $\mathrm{H} 37 \mathrm{Rv}$ & 345 & M-12 & M-20 \\
\hline $\begin{array}{l}\text { Bocconia arborea } \\
\text { (Papaveraceae) }\end{array}$ & $\begin{array}{l}1(\mathrm{~A}) \\
\mathbf{2}(\mathrm{A}) \\
\mathbf{3}(\mathrm{A}) \\
\mathbf{5}(\mathrm{A}) \\
\mathbf{6}(\mathrm{A})\end{array}$ & 13 & $\begin{array}{c}25 \\
12.5 \\
50 \\
50 \\
12.5\end{array}$ & $\begin{array}{c}>200 \\
50 \\
>200 \\
25 \\
12.5\end{array}$ & $\begin{array}{c}>200 \\
50 \\
>200 \\
50 \\
12.5\end{array}$ & $\begin{array}{l}>200 \\
25 \\
>200 \\
12.5 \\
12.5\end{array}$ \\
\hline $\begin{array}{l}\text { Stephania dinklagei } \\
\text { (Menispermaceae) }\end{array}$ & $\begin{array}{l}8(\mathrm{~A}) \\
9(\mathrm{~A})\end{array}$ & 7 & $\begin{array}{c}3.125 \\
50\end{array}$ & $\begin{array}{l}>200 \\
>200\end{array}$ & $\begin{array}{l}>200 \\
>200\end{array}$ & $\begin{array}{c}100 \\
>200\end{array}$ \\
\hline $\begin{array}{l}\text { Cephaelis dichroa } \\
\text { (Rubiaceae) }\end{array}$ & $\begin{array}{l}10(\mathrm{~A}) \\
12(\mathrm{~A})\end{array}$ & 11 & $\begin{array}{l}>50 \\
6.25\end{array}$ & $\begin{array}{l}100 \\
200\end{array}$ & $\begin{array}{l}>200 \\
>200\end{array}$ & $\begin{array}{l}>200 \\
>200\end{array}$ \\
\hline $\begin{array}{l}\text { Teloxys graveolens } \\
\text { (Chenopodiaceae) }\end{array}$ & $17(\mathrm{~F})$ & 5 & 12.50 & 200 & $>200$ & $>200$ \\
\hline $\begin{array}{c}\text { Psychotria camponutans } \\
\text { (Rubiaceae) }\end{array}$ & $\mathbf{2 3}(\mathrm{Q})$ & 12 & 12.50 & 200 & $>200$ & 100 \\
\hline $\begin{array}{l}\text { Stephania dinklagei } \\
\text { (Menispermaceae) }\end{array}$ & $24(\mathrm{Q})$ & 7 & 6.25 & $>200$ & $>200$ & $>200$ \\
\hline $\begin{array}{l}\text { E. platycarpa } \\
\text { (Leguminosae) }\end{array}$ & $25(\mathrm{~T})$ & 14 & 50 & $>200$ & $>200$ & $>200$ \\
\hline $\begin{array}{c}\text { Celaenodendron mexicanum } \\
\text { (Euphorbiaceae) }\end{array}$ & $\begin{array}{l}\mathbf{2 6}(\mathrm{T}) \\
\mathbf{2 8}(\mathrm{T}) \\
\mathbf{2 9}(\mathrm{T})\end{array}$ & 6 & $\begin{array}{l}25 \\
50 \\
50\end{array}$ & $\begin{array}{c}\mathrm{NT}^{\mathrm{b}} \\
>200 \\
200\end{array}$ & $\begin{array}{c}\mathrm{NT}^{\mathrm{b}} \\
>200 \\
>200\end{array}$ & $\begin{array}{l}\mathrm{NT}^{\mathrm{b}} \\
>200 \\
>200\end{array}$ \\
\hline & $\begin{array}{l}\text { Standard drugs } \\
\text { Isoniazid } \\
\text { Ethambutol } \\
\text { Rifampicin } \\
\text { Streptomycin }\end{array}$ & & $\begin{array}{c}0.06 \\
2.0 \\
0.06 \\
0.50\end{array}$ & $\begin{array}{c}<50 \\
12.50 \\
<50 \\
3.125\end{array}$ & $\begin{array}{c}<50 \\
12.50 \\
<50 \\
12.50\end{array}$ & $\begin{array}{c}<50 \\
12.50 \\
<50 \\
25\end{array}$ \\
\hline
\end{tabular}

${ }^{a}$ A: Alkaloid, F: Flavonoid, Q: Quinone, T: Triterpene, D: Diterpene. ${ }^{\mathrm{b}}$ NT: not tested.

$12.5 \mu \mathrm{g} / \mathrm{ml}$ ), isolated from Bocconia arborea. Interestingly, while 6-methoxy-dihydrochelirubine showed the same activity (MIC $12.5 \mu \mathrm{g} / \mathrm{ml}$ ) against the sensitive strain and MDR clinical isolates, the other two alkaloids were more active against the sensitive bacteria. Phaeanthine (13) and 1-hydroxy-benzoisochromanquinone (23) showed moderate activity against the sensitive bacteria and displayed only weak activity (MIC: $100-200 \mu \mathrm{g} / \mathrm{ml}$ ) against three and two of the resistant bacteria, respectively.
Liriodenine (8), the most active metabolite against the sensitive strain showed only moderate activity (MIC $100 \mu \mathrm{g}$ / $\mathrm{mL}$ ) against only one of the MDR isolates. Similarly, peracetylstrictosidine lactam (12), 3-oxo-7,24Z-dien-tirucalla-26-oic acid (29) and 5 $\alpha$-lanosta-7,9(11),24-triene-3 $\alpha, 23$-diol (32), as well as 5,7-dihydroxy-6-methyl-8-prenyl-flavone (15) and pinostrobin (17) showed moderate to good activity against the sensitive strain and showed only weak activity (MIC: $200 \mu \mathrm{g}$ / $\mathrm{mL}$ ) against one MDR isolate. 
In assessing structure-activity relationships, the higher activity of 6-methoxy-dihydrochelerythrine (2), compared to that of dihidrochelerythine (1) might be explained by a higher lipophilicity of the former, which may facilitate its passage across the cell membrane of the mycobacteria. A similar argument might be made for the following pair of metabolites: peracetylstrictosidine lactam (12) and strictosidine lactam (11); 5,7-dihydroxy-6-methyl-8-prenyl-flavanone (15) and 5,7-dihydroxy-8-prenyl-flavanone (14); pinostrobin (17) and pinocembrin (16); and 23-hydroxy-5 $\alpha$-lanosta-7,9(11),24-triene-3-one (33) and 5 $\alpha$-lanosta-7,9(11),24-triene-3á,23-diol (32), with the exception of acetyl oleanolic acid (25) and oleanolic acid (26).

The antimycobacterial activity detected for $\mathbf{2 5}$ and $\mathbf{2 6}$ is in agreement to that previously reported $[17,18]$. A comparison of the diterpene epimers of sandaracopimaradiene indicates that the configuration of the hydroxyl group at C-2 is important for activity, since ent-8(14),15-sandaracopimaradiene-2 $\alpha, 18$-diol (34) was twice as active as ent-8(14),15-sandaracopimaradiene-2 $\beta, 18$-diol (35) against the sensitive strain. A similar trend was observed between oleanolic acid (25) and epi-oleanolic acid (26).

Finally, it has been reported that the benzo(c)phenanthridine alkaloids chelerythrine and chelirubine inhibited the growth of $M$. tuberculosis $\mathrm{H} 37 \mathrm{Rv}$ by $\geq 94 \%$ at $12.5 \mu \mathrm{g} / \mathrm{mL}$ [3]. We found that dihydrochelerythrine (1, MIC: $25 \mu \mathrm{g} / \mathrm{mL})$ was half as active as chelerythrine against the sensitive strain, whereas 6-methoxy-dihydrochelirubine (6) has the same activity (MIC: $12.5 \mu \mathrm{g} / \mathrm{mL}$ ) against the sensitive and multidrugresistant isolates.

The results obtained in this evaluation indicate that the structural skeletons of the most active alkaloids 6-methoxydihydrochelirubine (6) and liriodenine (8) represent useful templates for the development of new anti-tuberculosis drugs.

\section{Experimental}

\section{Preparations of samples for testing}

Phytochemicals were isolated and identified previously by Camacho et al. [5-10], Solis et al. [11,12], Navarro et al. [13], Narváez-Mastache et al. [14]. The purity of the natural products and derivatives was determined by HPLC. Stock solutions were prepared by dissolving the various metabolites in dimethylsulfoxide at a concentration of $20 \mathrm{mg} / \mathrm{mL}$ and stored at -70 ${ }^{\circ} \mathrm{C}$ until use. Before the assay, stock solutions were four-fold diluted in supplemented Middlebrook 7H9 media.

\section{M. tuberculosis strains}

For the present study, the following bacteria were used: M. tuberculosis H37Rv American Type Culture Collection (ATCC) 27294, streptomycin, isoniazid, rifampicin, ethambutol, and pyrazinamide-sensitive; MDR M. tuberculosis clinical isolates (M-12, M-20 y 345) obtained from Secretaría de Salud de Tamaulipas, Jurisdicción Sanitaria IV, Reynosa,
Tamaulipas, México. The local ethics committee approved all protocols used in this study.

\section{Preparation of test inoculum}

Each mycobacteria was cultured at $37{ }^{\circ} \mathrm{C}$ in Middlebrook $7 \mathrm{H} 9$ broth supplemented with $0.2 \%$ glycerol and $10 \%$ OADC (oleic acid albumin dextrose catalase, Becton, Dickinson and Company, USA) until logarithmic growth was achieved. Each culture was mixed with a sufficient volume of sterile supplemented Middlebrook $7 \mathrm{H} 9$ broth to reach turbidity equivalent to that of McFarland's nephelometer No. 1 standard. The suspension was then diluted 1:20 with the same culture medium immediately before use in antimycobacterial test.

\section{Antimycobacterial test}

The activity of all phytochemicals against the aforementioned M. tuberculosis strains was tested using the microplate Alamar Blue assay described previously $[15,16]$. Sterile distilled water $(200 \mathrm{~mL})$ was poured into outer perimeter wells of the microplate. All other wells received $100 \mathrm{~mL}$ of supplemented Middlebrook 7H9 broth, then working metabolites solutions $(100 \mathrm{~mL})$ were poured into the first well of each row, from which two-fold dilution series were made through the microplate column. The test inoculum $(100 \mathrm{~mL})$ was added to all testing wells, as well as to the drug-free control wells. The final concentration of DMSO in wells was $<1 \% \mathrm{v} / \mathrm{v}$. At the same time, 100:100, 10:100 and 1:100 diluted controls were prepared from the bacterial suspension, representing the growth of 100,10 and $1 \%$ of the bacterial population tested. The final concentrations of metabolites tested ranged from 200 to $0.097 \mathrm{mg} / \mathrm{ml}$. Each concentration was assayed in duplicate. Each microplate was incubated for 5 days at $37^{\circ} \mathrm{C}$ in a $5 \%$ $\mathrm{CO}_{2}$ atmosphere in a sealed plastic bag. After incubation time, one control growth was developed with a mixture of $20 \mathrm{~mL}$ of Alamar blue solution (Trek Diagnostics, Westlake $\mathrm{OH}$ ) and 12 $\mathrm{mL}$ of sterile $10 \%$ Tween 80 . The plates were re-incubated at $37{ }^{\circ} \mathrm{C}$ for $24 \mathrm{~h}$. After incubation time, if the well turned pink, all the wells received the mixture of Alamar blue and Tween solutions in the same way and were incubated for an additional $24 \mathrm{~h}$. Wells with a well-defined pink color were scored as positive for growth. The Minimal Inhibitory Concentration (MIC) was defined as the lowest concentration of sample that prevents a color change to pink. Streptomycin, isoniazid, ethambutol and rifampicin were included as standard drugs. Each experiment was performed at least twice.

\section{Acknowledgments}

Dr. Virgilio Bocanegra-García provided multidrug resistant isolated clinical strains. This study was supported by the following grants: PROMEP/103.5/04/1371, PAICYT SA99304, CONACYT SALUD2004-C01-161and SIP/IPN. JLH is COFAA, SNI and EDI fellow and acknowledges their support. 


\section{References}

1. World Health Organization, Global tuberculosis control: surveillance, planning, financing. WHO report 2008, Geneva, 2008 (WHO/HTM/TB/2008.393).

2. Newton, S. M.; Lau, C.; Wright, C. W. Phytother. Res. 2000, 14, 303-322.

3. Copp, B. R. Nat. Prod. Rep. 2003, 20, 535-557.

4. Okunade, A. L.; Elvin-Lewis, M.P.F.; Lewis, W. H. Phytochemistry 2004, 65, 1017-1032.

5. Camacho, M. R.; Sánchez, B.; Quiroz, H.; Contreras, J. L.; Mata, R. J. Ethnopharm. 1991, 31, 383-389.

6. Camacho, M.R.; Mata, R.; Castañeda, P.; Kirby, G. C.; Warhurst, D. C.; Croft, S. L.; Phillipson, J. D. Planta Med. 2000; 66, 463468

7. Camacho, M. R.; Kirby, G. C.; Warhurst, D. C.; Croft, S. L.; Phillipson, J. D. Planta Med. 2000, 66, 478-480.

8. Camacho, M. R.; Phillipson, J. D.; Croft, S. L.; Kirby, G. C.; Warhurst, D. C.; Solis, P.N. Phytochemistry 2001, 56, 203-210

9. Camacho, M. R.; Phillipson, J. D.; Croft, S. L.; Rock, P.; Marshall, S. J.; Schiff, P. L. Jr. Phytother. Res. 2002, 16, 432-436.

10. Camacho, M. R.; Phillipson, J. D.; Croft, S. L.; Marley, D.; Kirby, G. C.; Warhurst, D. C. J. Nat. Prod. 2002, 65, 1457-1461.
11. Solis, P. N.; Wright, C. W.; Gupta, M. P.; Phillipson, J. D. Phytochemistry 1993, 33, 1117-1119.

12. Solis, P. N.; Lang'at, C.; Gupta, M. P.; Kirby, G. C.; Warhurst, D. C.; Phillipson, J. D. Planta Med. 1995, 61, 62-64.

13. Navarro, V.; Delgado, G. J. Ethnopharmacol. 1999, 66, 223-226. Navarro, V.; Rojas, G.; Delgado, G.; Lozoya, X. Arch. Med. Res. 1998, 29, 191-194.

14. Narváez-Mastache, J. M.; Garduño-Ramírez, M. L.; Álvarez, L.; Delgado, G. J. Nat. Prod. 2006, 69, 1687-1691. NarváezMastache, J. M.; Soto, C.; Delgado, G. Biol. Pharm. Bull. 2007, 30, 1503-1510

15. Collins, L.; Franzblau, S. G. Antimicrob. Agents Chemother. 1997; 41, 1004-0000.

16. Jiménez-Arellanes, A.; Meckes, M.; Ramírez, R.; Torres, J.; Luna-Herrera, J. Phytother. Res. 2003, 17, 903-938.

17. Wachter, G. A.; Valcic, S.; Flagg, M. L.; Franzblau, S. G.; Montenegro, G.; Suárez, E.; Timmermann, B. N. Phytomedicine 1999, 6, 341-345.

18. Caldwell, G. C.; Franzblau, S. G.; Suarez, E.; Timmermann, B. N. J. Nat. Prod. 2000; 63, 1611-1614. 


\section{Sociedad Química de México}

dheimer, Gilbert stork, Raul cetina, Guillermo Carvajar,

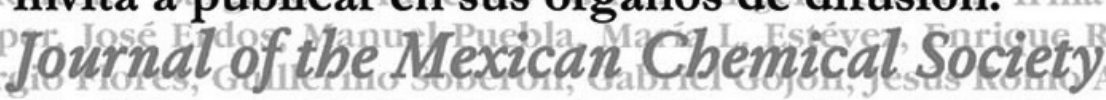
(de 1957 a 2004: Revista de 1a Sociedád Química de México www.jmcs,org.mx) y yen el Boletiñ dela Sociedad Químicdede México (www:bsqm.org.mx).
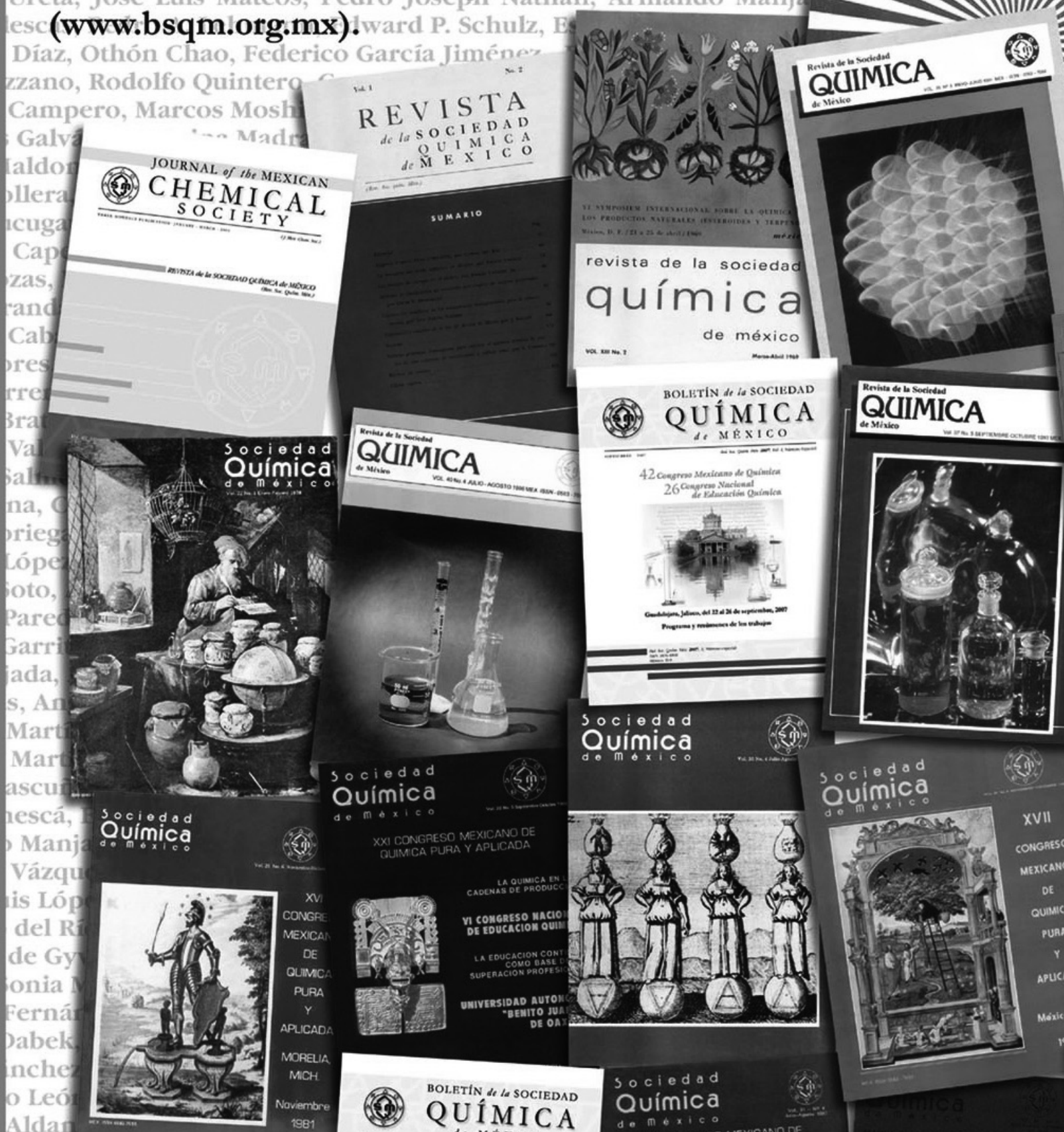

de la SOCIEDAD REvista of LA SOCIE QUÍMICA química

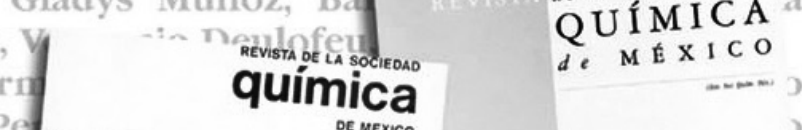

(3.2

\section{Sociedad}
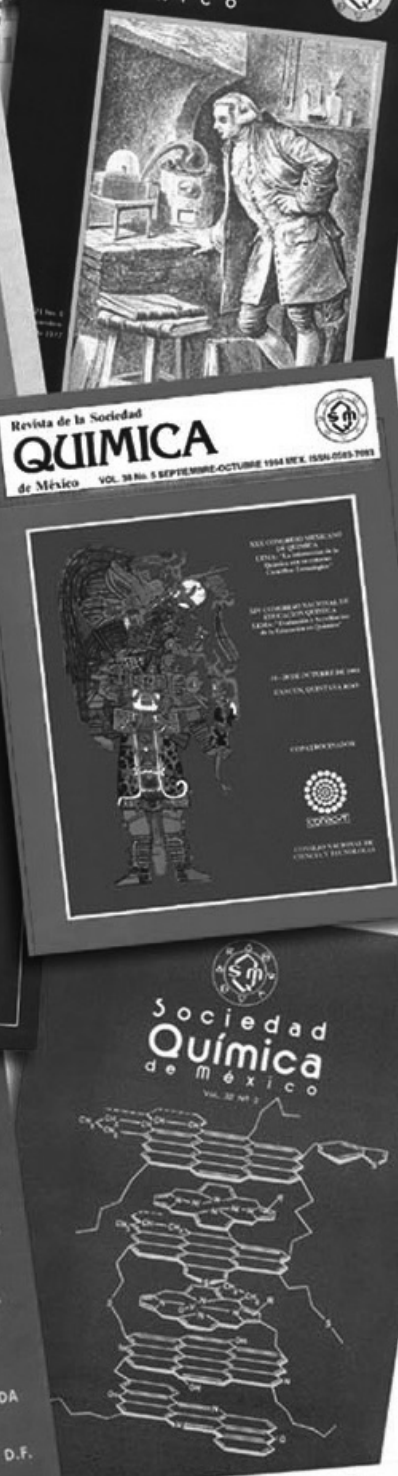

Quimica

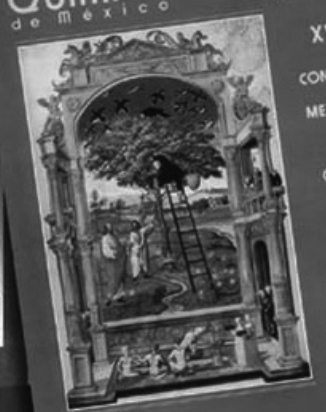

(30) QULETIN U L L SOCIEDAD
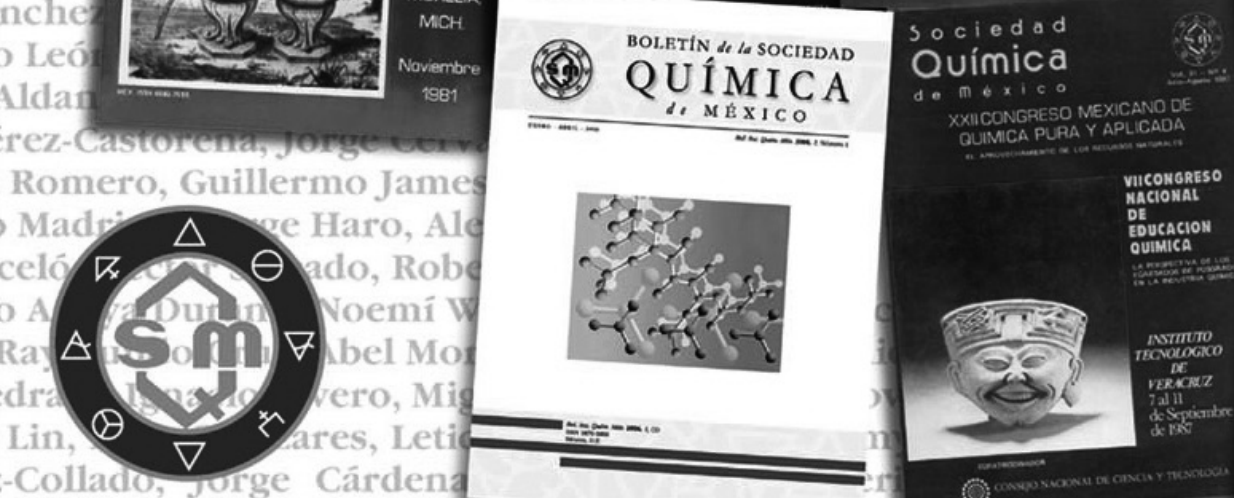

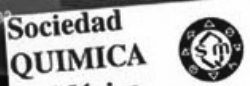
de México

ำ

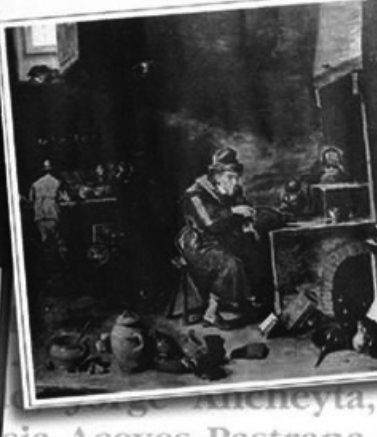

SOCIEDAD QUÍMICA DE MÉXICO, A.C. Barranca del Muerto 26, México 03940, D. F. Tel: (52) (55) 56626837 